\title{
Impact of Climate Change on Smallholder Dairy Production and Coping Mechanism in Sub-Saharan Africa - Review
}

\author{
Gezu Tadesse ${ }^{1 *}$ and Moges Dereje ${ }^{2}$ \\ ${ }^{1}$ Department Animal Science, Wachemo University, Ethiopia \\ ${ }^{2}$ School of Animal and Range Science, Haramaya University, Ethiopia
}

Submission: May 04, 2018; Published: June 21, 2018

"Corresponding author: Gezu Tadesse, Animal Science department, Wachemo University, Ethiopia, Email: gezutadesse@gmail.com

\begin{abstract}
The current problems in the world are variation/declining of rainfall, shortage of feed and water, incidence of disease and rising of temperature, these are come about because of climate change. So, the objective of this review is to appraisal the impact of climate change on smallholder dairy production and coping mechanism in sub-Saharan Africa. Climate change is a long-term and significant change in the expected patterns of a specific region's average weather for an appropriately significant period of time caused by the accumulation of greenhouse gases (gases facilitate for climate change are $\mathrm{CO}_{2}, \mathrm{CH}_{4}$ and $\mathrm{N}_{2} \mathrm{O}$ ) in the atmosphere which leads to global warming. Africa has been identified as one of the parts of the world most vulnerable to the impacts of climate change. Though climate change affect livestock production directly and indirectly, can be mitigate through adaptation measures involve production and management system modifications, breeding strategies, institutional and policy changes, science and technology advances, and changing farmers' perception, manure management, shifting dietary and reducing enteric methane production.
\end{abstract}

Keywords: Climate Change; Smallholder dairy production; Mitigation; Sub saharan africa

Abbreviations: GHG: Greenhouse Gas; $\mathrm{T}^{\circ}$ : Temperature; $\mathrm{CO}_{2}$ : Carbon Dioxide; $\mathrm{CH}_{4}$ : Methane; $\mathrm{N}_{2} \mathrm{O}$ : Nitrous Oxide; $\mathrm{CCV}$ : Climate Change and Variability; CF: Carbon Footprint; $\mathrm{CO}_{2}$-eq: $\mathrm{CO}_{2}$ equivalent; TNZ: Thermoneutral Zone

\section{Introduction}

Climate change is the planet's biggest threat, affecting land and water availability and crop yields at a time when populations are rising fast, periodically causing food crises. Globally, there is an urgent need to reduce the greenhouse gas (GHG) emissions that cause climate change by at least $80 \%$ in wealthy countries and to protect the biodiversity which underpins food production [1]. Climate change refers to a change in the state of the climate that can be identified (e.g. using statistical tests) by changes in the mean and/or the variability of its properties and that persists for an extended period and warming of the global climate is now unequivocal. Climate change is characterized by increasing temperature and related climate phenomena, including an increase in the frequency and intensity of extreme weather events such as hot spells, droughts and floods, and an increase in climatic uncertainty [2,3]. Most climatologists agree that the increase in green-house gases atmosphere is causing an increase in air temperature $\left(\mathrm{T}^{\circ}\right)$ and that future increases in temperature pose a clear and present danger to the distribution and abundance of animal and plant populations worldwide.
Even though a large number of people doubt the reality of global warming, and others simply choose to ignore it, the increase in the earth's air temperature over the last 100 years seems incontrovertible, as does the fact that these increases are not a result of natural phenomenon [4]. The global average surface temperature increased by about $0.6^{\circ} \mathrm{C}[5]$ or $0.7^{\circ} \mathrm{C}[4]$ during the twentieth century. The variation of rainfall in time and in space has undergone wide changes and the level of sea water rose by approximately $25 \mathrm{~cm}$. The increase in temperature has already affected the biological systems on earth, and the changing in species distribution, the size of populations, seasons of reproduction and migration of animals and a higher occurrence of parasites and diseases in the forest system [4].

Heat-trapping gases (also known as greenhouse gases) like water vapor, carbon dioxide, ozone, methane, and nitrous oxide, which absorb heat radiated from the Earth's surface and lower atmosphere and then radiate much of the energy back towards the surface. Animal farming contributes to GHG emissions through several routes. The most significant are carbon dioxide 
from land use and its changes (32\%) nitrous oxide from manure and slurry (31\%) and methane from animal digestion (25\%) [1]. Direct and indirect sources of GHG emissions in animal production systems include physiological processes from the animal (enteric fermentation and respiration), animal housing, manure storage, treatment of manure slurries (compost and anaerobic treatment), land application, and chemical fertilizers [6].

Agriculture is an important source of global emissions GHG, mainly from ruminant production. The negative impact of animal production is due to two main factors: the atmospheric pollution (carbon dioxide and methane and manure management and nitrogen emission from soils) and water and soil pollution (nitrogen and phosphorus). The methane emissions are mainly due to ruminant farming as the ruminants emit methane as part of their digestive process (enteric fermentation), manure management and other processes [7]. Dairy farming has been part of agriculture for thousands of years [8]. Direct effects from air temperature, humidity, wind speed and other climate factors influence animal performance: growth, milk production, wool production and reproduction [9]. Direct emissions refer to emissions directly produced from the animal including enteric fermentation and manure and urine excretion [10]. Climatic influences on the quantity and quality of feedstuffs such as pasture, forage, grain and the severity and distribution of livestock diseases and parasites [11]. In the decades to come, if they are to survive, species will need to alter their distribution patterns, change their behavior patterns, and/ or make adjustments in their physiology, either by short-term acclimation through phenotypic flexibility or by longer-term evolutionary shifts in physiological phenotype by means of natural selection [12]. Though, the climate change is increases, it needs to take a cope mechanism through for selecting for 'environmental fit' which aim for a good match between the end result of the selection process, in terms of genetic change, and the environment, or system, in which animals are reared and maintained [13]. Therefore, the objective of this review is to design the impact of climate change on smallholder dairy production and coping mechanism in sub-Saharan Africa

\section{Dairy Production Systems in Sub-Saharan Africa}

The consequences of increase population, rapid growth in demand, urbanization, combined with slowing scope for supply response from traditional producing regions has resulted in increased sensitivity of agricultural markets to supply variations due to weather [14]. There are three major land-based systems producing milk in SSA, pastoralists, agro pastoralists and croplivestock farmers [15]. Dairy production is practiced almost all over Ethiopia involving a vast number of small subsistence and market-oriented farms $[16,17]$. There are different types of milk production systems can be identified based on various criteria [18]. Based on climate, land holdings and integration with crop production as criterion, the dairy production system classified as rural (pastoralism, agro-pastoralism and highland mixed smallholder), peri-urban and urban. The dairy sector in Ethiopia also categorized based on market orientation, scale, and production intensity, there are three major production systems identified: traditional smallholders privatized state farms, and urban and peri urban systems $[19,20]$.

\section{Definition of Climate Change}

It is the significant variation of the mean state (long term or permanent sift climate) of climate relevant variables such as temperature, precipitation/rainfall (timing and quantity), $\mathrm{CO}_{2}$, solar radiation and the interaction of these elements and wind in a certain period of time, commonly over 30 years $[2,21]$. On the other hand, climate change is defined as any long-term and significant change in the expected patterns of a specific region's average weather for an appropriately significant period of time. It is the result of several factors, including earth's dynamic processes, external forces, and more recently, human activity. External factors that shape climate include such processes as variations in solar radiation, deviations in earth's orbit, and variations in the level of greenhouse gas concentrations. Evidence of climatic change taken from a variety of sources can, in turn, be used to reconstruct past climates. Most climate evidence is inferred from changes in key climate indicators, including vegetation, ice cores, dendrochronology, sea-level change, and glacial geology [22].

\section{Factors (Causes) for Climate Change}

Climate change is caused by accumulation of greenhouse gases (GHG) in the atmosphere which leads to global warming [3]. At global scale, three major gases facilitate climate change: carbon dioxide $\left(\mathrm{CO}_{2}\right)(70 \%$, primarily from burning of fossil fuel (petroleum) imported from industrialized countries), methane $\left(\mathrm{CH}_{4}\right)$, and nitrous oxide $\left(\mathrm{N}_{2} \mathrm{O}\right)$ caused by deforestation and agricultural activities, particularly the use of pesticides [23]. Livestock contribute to climate change by emitting greenhouse gases, either directly (e.g. from enteric fermentation) or indirectly (e.g. from feed-production activities, deforestation, overgrazing, etc.). Greenhouse gas emissions can emanate from all the main steps of the livestock production cycle. Contributions of livestock activities to carbon cycle may therefore have an important impact on the process of global warming. At the farm level, $\mathrm{CH}_{4}$ and $\mathrm{N}_{2} \mathrm{O}$ are emitted from enteric fermentation and manure. In ruminant species, $\mathrm{CH}_{4}$ is exhaled as a by-product of the process of fermentation of fibrous feedstuffs in the rumen. Nitrous oxide is released from manure during storage and spreading, and $\mathrm{CH}_{4}$ is also generated when manure is stored in anaerobic and warm conditions [24].

\section{Climate Change in Sub-Saharan Africa}

Africa has been identified as one of the parts of the world most vulnerable to the impacts of climate change [25]. The climate of Africa is warmer than it was 100 years ago and modelbased predictions of future GHG induced climate change for 
the continent clearly suggest that this warming will continue and, in most scenarios, accelerate [26,27]. Climate change and variability (CCV) in Sub-Saharan Africa is already impacting negatively on rain-fed agriculture and livestock systems. The CCV are caused by both natural and human related activities. There are many complex and interrelated issues that contribute to this state of affairs. Probably more than $90 \%$ of the activities of humankind are largely responsible for the current day CCV. Climate change and variability complexities are exacerbated by increasing human population and demand for more agricultural land for food production, resulting in the destruction of the vegetation cover and subsequently rampant environmental degradation [27].

Changes in Africa's mean annual rainfall are projected to be modest and varied. Rainfall is projected to decline in southern Africa and the Horn of Africa by $10 \%$, and is projected to rise by up to $16 \%$ in the Sahel (although not all models agree with this prognosis). The problem in modeling potential rainfall change in the Sahel is the large degree of natural variability in total annual rainfall that already occurs in the region and the relatively shortterm records that are available [28]. Climate change is an added stress to already threatened habitats, ecosystems and species in Africa, and is likely to trigger species migration and lead to habitat reduction. Up to $50 \%$ of Africa's total biodiversity is at risk due to reduced habitat and other human-induced pressures [29].
The East Africa region is characterized by wide diverse climates from desert to forest over comparatively small areas. In the past, the region has been prone to floods and drought which have had severe negative impacts on key sectors of economies of most countries of East Africa. These include agricultural production, health status, water availability, energy use and biodiversity and ecosystem services (including tourism). In the late seventies and eighties drought caused widespread famine and economic hardships. Reports from risk assessment studies indicate that that future climate change may lead to a change in the frequency or severity of such extreme weather events, potentially worsening these impacts, together with annual and seasonal rainfall changes. In addition, the extreme weather events such as drought and floods will have a potential negative consequence on livestock-agriculture sector [30]. Any outcome of the impact will have a strong distributional pattern and amplify inequalities in health status and access to resources, due to apparent spatial variations in vulnerability. Furthermore, vulnerability is exacerbated by existing developmental challenges and low adaptive capacity of rural communities. Smallholder dairy farmers produce milk in diverse production environments where productivity of dairy breeds is increasingly challenged directly and indirectly with the impacts of variable and changing climate. Increasing ambient temperatures directly impact heat load stress on the animals while feed resource base worsens with more frequent droughts and climate change induced outbreaks of transboundary animal diseases [31] (Figure 1).

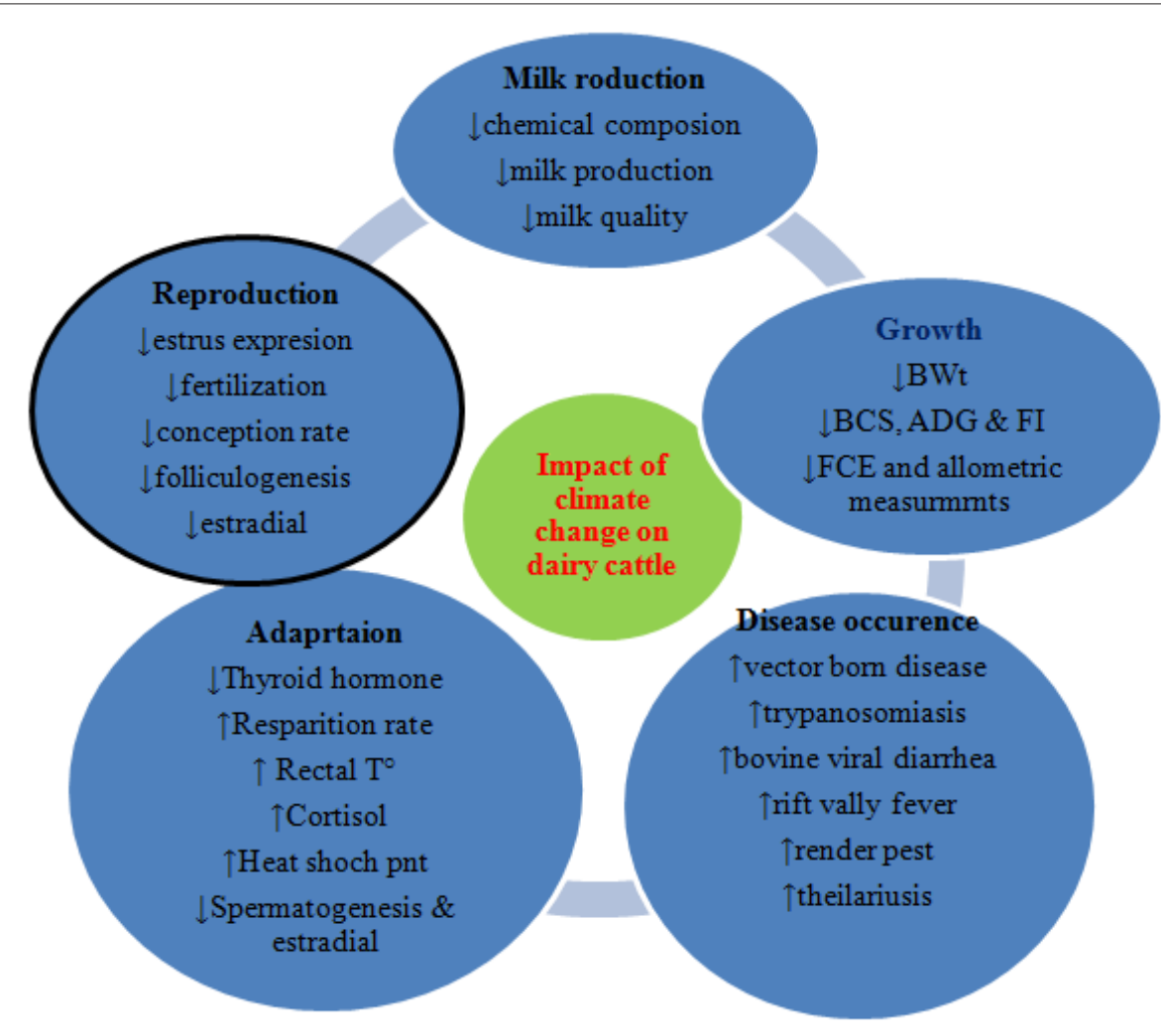

Figure 1: Summary of climate change on dairy cattle in Sub-Saharan Africa. 


\section{Impact of Dairy Cattle on Climate Change}

Dairy production plays a part in greenhouse gases (GHGs) emissions, particularly methane, which contributes to climate change [32]. Livestock sector as a whole is responsible for $18 \%$ of total anthropogenic GHG emissions measured in carbon dioxide $\left(\mathrm{CO}_{2}\right)$ equivalent [33], and global dairy production accounts for $4 \%$ of the total global anthropogenic GHG emissions [34]. Very high carbon footprint (CF) of milk in Sub-Saharan Africa is due to a particularly low milk yield (less than $500 \mathrm{~kg}$ per cow and year) and a high age of cows when having their first calf [35]. GHG emissions from raw milk production at farm level have a dominating influence (70-90\%) on the carbon footprint (CF) of dairy products. $\mathrm{CH}_{4}$ (from enteric fermentation and manure management) and $\mathrm{N}_{2} \mathrm{O}$ (from production and use of fertiliser) are the main sources of emissions making up about $70-90 \%$ of total GHG emissions at the primary production stage [35]. $\mathrm{CH}_{4}$ is produced naturally by microbial fermentation in the rumen of dairy cows. More than $95 \%$ of the $\mathrm{CH}_{4}$ comes from belching, while only a minor proportion is produced in the large intestine and passed out as flatulence. Thus, $\mathrm{CH}_{4}$ is a natural process and a condition affecting ruminants that convert grass and other plants, not digestible to humans, to valuable products such as milk and meat. $\mathrm{CH}_{4}$ production is an energy loss for the animal, and loss of $\mathrm{CH}_{4}$ (or ' $\mathrm{CH}_{4}$ conversion factor') is dependent on the type and quality of the feed and is typically between $4 \%$ and $10 \%$ of the gross energy intake for ruminants [36].

\section{Impact of Climate Change on Smallholder Dairy Production in Sub-Sahara Africa}

Dairy farming is vulnerable to climate change through increased temperatures and changes in rainfall patterns [32]. Africa's livestock sector will be specifically affected by climate changes through changes in the pattern and quantity of rainfall; an increase in temperature; changes in winds; changes in seasonality; more frequent catastrophic events; a decrease in feed and fodder production; reduced water availability; changing patterns and distribution of disease; changes in the marketing and prices of commodities. The effects of climate change on livestock production and health could be an additional significant burden to the already existing problems that hold back livestock development in Africa [37]. In addition, lack of economic development and institutional capacity makes the situation more challenging. Significantly, the climate variability will have a serious effect on pastoralists whose livelihood depends upon livestock for food, economic security and cultural preservation. The impact of climate change also increases the problem of water scarcity; pasture land shortage and diseases dynamics [38]. The measure of climate change in dairy farms can be achieved by using the emissions of methane by the ruminants converted in $\mathrm{CO}_{2}$ equivalent $\left(\mathrm{CO}_{2}\right.$-eq) [07]. Climate change will have tremendous consequences for dairy, meat and wool production, mainly arising from its impact on grassland and rangeland productivity. Climate change will affect livestock production through competition for natural resources, quantity and quality of feeds, livestock diseases, heat stress and biodiversity loss while the demand for livestock products is expected to increase by $100 \%$ by mid of the $21^{\text {st }}$ century [38].

\section{Effect on milk production}

There is a particular temperature zone in which lactating dairy cows feel comfort and produce at an optimal level. Lactating dairy cows prefer ambient temperatures ranging from $5{ }^{\circ} \mathrm{C}$ and $25{ }^{\circ} \mathrm{C}$, the 'thermoneutral' zone (TNZ). When environmental temperatures move out of the thermoneutral zone (or comfort zone) dairy cattle begin to experience either heat stress or cold stress. In dairy cows, studies have considered two critical THI thresholds [39]: Milk production starts to decline at THI above 72 for cows which have no access to shade, but important declines occur at THI above 78 for cows having access to shade and a sprinkler system [40]. High productive animals having high endogenous heat production, exhibit tolerance to heat. Holstein dairy cow is the primary target of heat stress relief, followed by feedlot cattle [41]. A thermal environment is a major factor that affects milk production in dairy cow especially on animals of high genetic merit, and milk yield decline by $0.2 \mathrm{~kg}$ per unit increase THI when it exceeded 72 [42]. The reduction in milk production caused by heat stress could be the result of decreased nutrient intake and nutrient uptake by the portal drained viscera of the cow. Blood flow shifts to peripheral tissues for cooling purposes, alter nutrient metabolism and contribute to lower milk yield. The increase in milk yield increase sensitivity of animals to thermal stress and decline the threshold temperature at which milk losses occur [41]. During late pregnancy and the early post-partum period, hot environment negatively affects milk quality, leads to lower colostrum net energy fat and protein content. In addition, the analysis of protein fractions showed a reduction in percentages of casein, lactoalbumin, $\operatorname{IgGm}$ and $\operatorname{IgA}$ [43]. Heat and nutritional stresses in dairy cows reduce herd productivity and profitability through mortality, reduced growth and reproduction, which can be of substantial economic loss to producers utilising less adaptable breeds. Heat stress has a variety of detrimental effects on livestock with significant effects on milk production and reproduction in dairy cows.

\section{Effect on growth}

Temperatures ranging between $15^{\circ} \mathrm{C}$ and $29^{\circ} \mathrm{C}$ do not seem to have any effect on growth performance. The effects of high ambient temperature on growth performance are induced by the decrease of the anabolic activity and the increase in tissue catabolism [44]. The effect of climate change on growth, reduce body weight, reduce body condition score, reduce average daily body gain, reduce feed intake, and reduce feed conversion and allometric measurements. Heat distress suffered by animals will reduce the rate of animal feed intake and result in poor growth performance [45].

\section{Effect on reproduction performances}

High ambient temperature compromise reproductive efficiency of farm female and male animals. Cattle's fertility is 
reduced from around $50 \%$ in winter to less than $15 \%$ in summer. A drop can occur in summer of about a $20-27 \%$ [46]. In practice, dry pregnant cows are not protected from heat stress because they are not lactating, and it is incorrectly assumed that they are less prone to heat stress. The dry period is particularly crucial since it involves mammary gland involution and can affect endocrine responses that may increase foetal abortions, shorten the gestation length, lower calf birth weight, and reduce follicle and oocyte maturation associated with the postpartum reproductive cycle [47]. The somatic cells within the follicles (theca and granulosa cells) could be damaged by heat stress. Heat stress affects ovarian follicles and induces a decrease in estradiol synthesis [48]. It compromises oocyte growth in cows by altering progesterone, luteinizing hormone, and folliclestimulating hormone secretions during the oestrus cycle [49].

Rensis and Scaramuzzi [50] hypothesised that the dominant follicle develops in a low LH environment resulting in reduced estradiol secretion inducing poor expression of oestrus by reducing its length and intensity. Once ovulation occurs, the damaged oocyte has reduced chances of fertilizing and developing into a viable embryo. The ability of zygotes to develop blastocyst was reduced during summer. Heat stress can also affect the early developing embryo. When heat was applied from day 1 to day 7 after estrus, there was a reduction in embryo quality and stage from embryos flushed from the reproductive tract on day 7 after estrus. During pregnancy and prepartum heat stress could decrease thyroid hormones and placental estrogen levels, while increasing non-esterified fatty acid concentrations in blood; all of which can alter growth of the udder and placenta, nutrients delivered to the unborn calf, and subsequent milk production [51].

\section{Disease}

Livestock disease occurrence is based on disease ecology and transmission dynamics which can be influenced by environmental conditions. Bacterial, viral disease and parasitic infestation will be greatly influenced by changes in rise in temperature and humidity. Temperature sensitive diseases will be on the increase which may be considerable in high humidity and flooded areas. Disease challenges have already indicated that they are a major constraint to the improvement of the livestock industry in the tropics [52]. Expression of many livestock diseases and parasitic infestation are known to be climate dependent causing devastating illness and loss of body condition resulting in reduced animal performance. Livestock health may be affected heat-related diseases and stress, extreme weather events, adaptation of animal production systems to new environments, and emergence or reemergence of infectious diseases, especially vector-borne diseases critically dependent on environmental and climatic conditions [53]. Climate changerelated effects are likely to increase the importance of genetic resistance and tolerance in disease control strategies [04]. Under climate change, rising temperatures are changing the geographical distribution of disease vectors which are migrating to new areas and higher altitudes, for example, migration of the malaria mosquito to higher altitudes will expose large numbers of previously unexposed people to infection in the densely populated east African highlands [29]. Africa is vulnerable to a number of climate sensitive diseases including malaria, tuberculosis and diarrhoea [54]. Diseases in livestock result in severe effects on livestock survival, marketability, animal health and livelihoods [38].

\section{Indirect effects (feed and water availability) of climate change}

One of the most significant effects of climate change on livestock production is changing the animal feed resources [55]. Climate change and variability have the potential to impact negatively on changes in production and quality of feed crop and forage [56,57], water availability and access/demand particularly in Africa, animal growth and milk production, diseases, reproduction [58], and biodiversity. These impacts are primarily due to an increase in temperature and atmospheric carbon dioxide $\left(\mathrm{CO}_{2}\right)$ concentration, precipitation variation, and a combination of these factors [57]. According to IPCC [21] state, confident that the overall net impact of climate change on water resources and freshwater ecosystems will be negative due to diminished quantity and quality of available water. Africa will face increasing water scarcity and stress with a subsequent potential increase of water conflicts as almost all of the 50 river basins in Africa are trans-boundary [59].

Increasing heat stress will significantly increase water requirements for livestock, resulting in overgrazing near water points. As a result causing land degradation and endanger biodiversity [21]. For Bos indicus water intake increases from about $3 \mathrm{~kg}$ per $\mathrm{kg}$ DM intake at $10^{\circ} \mathrm{C}$ ambient temperature, to $5 \mathrm{~kg}$ at $30^{\circ} \mathrm{C}$, and to about $10 \mathrm{~kg}$ at $35^{\circ} \mathrm{C}$. Some of the greatest impacts of global warming will be visible in grazing systems in arid and semi-arid areas [60]. Increasing temperatures and decreasing rainfall reduce yields of rangelands and contribute to their degradation. Higher temperatures tend to reduce animal feed intake and lower feed conversion rates. There is also evidence that growing seasons may become shorter in many grazing lands, particularly in sub-Saharan Africa [45]. The spatial distribution and availability of pasture and water are highly dependent on the pattern and availability of rainfall [61]. Changes in the patterns of rainfall and ranges of temperature affect feed availability, grazing ranges, feed quality, weed, pest and disease incidence [62]. Thus, changes in climatic factors such as temperature, precipitation and the frequency and severity of extreme events like droughts directly affected livestock yields [63].

\section{Dairy Cattle Adaptation Strategies in Sub-Saharan Africa}

Adaptation and mitigation can make significant impacts if they become part of national and regional policies [64]. Adaptation measures involve production and management system modifications, breeding strategies, institutional 
and policy changes, science and technology advances, and changing farmers' perception and adaptive capacity $[57,65]$. Research is needed on assessments for implementing these adaptation measures and tailoring them based on location and livestock system [56]. Effective adaptation and adoption of new technologies, which contribute both to mitigation and the long term viability of farming, will require investments and planning efforts capacity of individual farms. Public authorities will have a role to play in supporting and facilitating climate change adaptation policies. In order to continue, livestock industries need to anticipate these changes, be prepared for uncertainty and develop adaption strategies [66].

Livestock producers have traditionally adapted to various environmental and climatic changes by building on their indepth knowledge of the environment in which they live [67]. Smallholder, subsistence, and pastoral systems, especially those located in marginal environments, areas of high variability of rainfall or high risks of natural hazards, are often characterized by livelihood strategies that have been evolved

i. To reduce overall vulnerability to climate shocks ("adaptive strategies")

ii. To manage their impacts ex-post ("coping strategies").

The distinction between these two categories is however frequently blurred: what start as coping strategies in exceptional years can become adaptations for households or whole communities. Many defining features of dry land livelihoods in Africa and elsewhere can be regarded as adaptive strategies to climate variability.

For example, Mortimore and Adams [68] for Northern Nigeria mention five major elements of adaptation:

i. Allocating farm labor across the season in ways that follow unpredictable intra-season rainfall variations: "negotiating the rain."

ii. Making use of biodiversity in cultivated crops and wild plants.

iii. Increasing integration of livestock into farming systems (at a cost of increased labor demands).

iv. Working land harder, in terms of labor input per hectare, without increasing external non-labor inputs

v. Diversifying livelihoods

In addition above mentioned, the following have been identified by FAO [64], Hoffmann [60], Sidahmed [67] and Thornton et al. [56] as ways to increase adaptation in the livestock sector:

\section{$\checkmark \quad$ Production adjustments}

o Diversification, intensification, integration of pasture management, livestock and crop production, changing land use and irrigation, altering the timing of operations, conservation of nature and ecosystems.

o Modifying stock routings and distances; introducing mixed livestock farming systems - i.e. stall-fed and pasture grazing.

\section{$\checkmark \quad$ Breeding management strategies}

o Changing the breeding animal for every 2-3 years (exchange from other district herd) or artificial insemination with proven breed semen will help in enhancing the productivity. This may be supplemented with supply of superior males through formation of nucleus herd at block level

o Local breeds are already adapted to their harsh conditions. However, developing countries are usually characterised by a lack of technology in livestock breeding and other agriculture programmes which might help to speed adaptation.

o Changes in breeding strategies can help animals increase their tolerance to heat stress and diseases and improve their reproduction and growth development [45]. Therefore, the challenge is in increasing livestock production while maintaining the valuable adaptations offered by breeding strategies, all of which will require additional research [69]. In addition, policy measures that improve adaptive capacity by facilitating implementation of adaptation strategies will be crucial [65].

$\checkmark$ Identifying the genes responsible for unique characteristics like disease tolerance, heat tolerance, ability to survive in low input conditions and using it as basis for selection of future breeding stock will help in mitigating the adverse effect of climate stress

$\checkmark \quad$ Capacity building livestock keepers - increased awareness of global changes, and improved capacity of herders/livestock producers to understand and deal with climatic changes. Training in agroecological technologies and practices for the production and conservation of fodder is improving the supply of animal feed, reducing malnutrition and mortality in herds

\section{$\checkmark \quad$ Farmers' perception and adaptive capacity}

o One of the limiting factors for these changes to succeed is the disposition and capability of farmers to recognize the problem and adopt climate change adaptation and mitigation measures [70]. Because of this, it is important to collect information about farmers' perceptions to mitigation and adaptation measures. One approach for collecting information about farmers' perceptions that has been used for mitigation and adaptation research is qualitative; using open-ended survey questions or group discussion at workshops to understand individual and group opinions. By understanding farmers' perceptions and including them in rural policy development, there is a greater 
chance of accomplishing food security and environmental conservation objectives. Risk perception within farmer decision-making can be increased through education, family farm succession, and social interaction among farmers and farming communities.

\section{$\checkmark \quad$ Science and technology development}

o Better understanding of the causes and impacts of climate change on livestock, development of new breeds and genetic types, improved animal health, and improved water and soil management.

$\checkmark \quad$ Improving local genetics through cross breeding with heat and disease tolerant breeds. If climate change is faster than natural selection the risk of survival and adaptation of the new breed becomes greater

$\checkmark \quad$ Identifying and strengthening local breeds which are adapted to local climatic stress and feed sources

o Increased awareness of global changes, and improved capacity of herders/livestock producers to understand and deal with climatic changes. Training in agro-ecological technologies and practices for the production and conservation of fodder is improving the supply of animal feed, reducing malnutrition and mortality in herds. Livestock management systems - efficient and affordable adaptation practices have to be developed for rural poor not able to buy expensive adaptation technologies.

$\checkmark \quad$ Institutional and policy changes: removal or putting in place of subsidies, insurance systems, income diversification practices as well as the introduction of Livestock Early Warning Systems, as in the case of IFADsupported interventions in and other forecasting and crisis preparedness systems

$\checkmark \quad$ Market responses: improvement of agriculture market, promotion of inter-regional trade, credit schemes

$\checkmark \quad$ Provision of shade and water to reduce heat stress from increased temperature

o Current high cost of energy, providing natural (low cost) shade instead of high cost air conditioning is more applicable to rural poor producers; Reduction of livestock numbers - lower number of more productive animals will cause more efficient production and lesser emission of GHG from livestock production Change in livestock/herd composition (large animal versus small animal, etc.

$\checkmark \quad$ Improved livestock management systems - efficient and affordable adaptation practices have to be developed for rural poor not able to buy expensive adaptation technologies.

\section{Genetic selection for environmental change adaptation}

Livestock genetic adaptation responses will vary from intensifying and managed systems to adaptive systems in more marginal environments. Traditionally, the selection of animals in tropical breeds has been an adaptive one, but in recent times, market pull has stimulated a rapidly changing demand for higher production that could not be met quickly enough by breed improvement of indigenous animals. Widespread cross-breeding of animals, mostly with "improver" breeds from temperate regions, crossed with local animals, has occurred - often with poor results. Little systematic study has been conducted on matching genetic resources to different farming and market chain systems from already adapted and higher producing tropical breeds. However, given the even greater climatic variability and stresses anticipated, this is a most logical response to the adaptive challenges that will be faced [69].

Genetic approach need to be developed and applied to help dairy industries mitigate impacts of CVC using genetic tools. Broader breeding goals have become the norm in the dairy, usually incorporating production and "fitness" (health, fertility, longevity) traits in developed world. However, exotic cattle produced from such breeding programmes faces challenges of genotype by environment interactions, hence there is a need to develop local breeding programme for specific production environment. Therefore, an economic evaluation of the different DBGs imported and across PEDs is necessary to identify the most suitable breed (s) for the different production environments. The assessment of the presence and magnitude of DBGs by environment interaction is needed, which will enable the achievement of optimum performance across the different environments. In the presence of breed by environment interactions, particular genotypes will be sought for particular environments in order to optimize total merit of production. Increased training to farmers on how to handle the DBGs is also necessary [71].

Breeding goals may have to be adjusted to account for higher temperatures, lower quality diets, and greater disease parasite challenge. Species and breeds that are well adapted to such conditions may become more widely used [60]. The methods by which $\mathrm{CH} 4$ emissions of individual animals can be measured are an important factor because the method used to measure the $\mathrm{CH} 4$ trait will also influence the resulting genetic parameters and is therefore an integral part of the selection programme [72]. In addition, locally adapted breeds are likely to be highly variable and the highest performing animals of such breeds can have great productive potential. Therefore, the screening of livestock populations previously not subjected to systematic selection is likely to give quicker results to provide high genetic merit foundation stock for nucleus flocks [73].

\section{Cope Mechanism for Climate Change/Method of Mitigation for Climate Change}

Livestock improvement strategies should focus on enhancing the ability of animal's survival on low quality feed, induced by unfavorable climatic conditions, tolerant to emerging diseases and slow emaciation rate during feed and water resource 
shortage should be integral part of an effective future livestock improvement strategy [74]. Current animal breeding systems are not sufficient to meet this need and the improvement of breeding programs under different livestock production and marketing contexts is a critical area for new research [70]. In the context of climate change there is need for selecting for 'environmental fit' which aim for a good match between the end result of the selection process, in terms of genetic change, and the environment, or system, in which animals are reared and maintained [13].

Attaining sustainable dairy productivity requires utilizing breeds adaptable to the variable and changing climate in order not to enter state of insecurities in food, nutrition, income and health of smallholder dairy farmers and their livestock assets. When adaptable dairy breeds are identified, they can be promoted in appropriate environments together with appropriate management interventions that effectively reduce animal stresses to changing climate to enable smallholder dairy farmers mitigate and adapt to effects of changing climate to maintain and sustain their livelihood assets. Indigenous cattle breeds such as Zebu and its crosses are highly adapted to the harsh conditions, poor nutrition and disease and parasite challenges. Their adaptation is attributed to different hereditary characteristics that have resulted in differences in reactions to environmental stimuli. These reactions are intimately associated with anatomical-physiological characteristics, which have developed as a result of natural selection. Conversely, indigenous cattle breeds possess genes and alleles that are pertinent to their adaptation to the local production environments [71].

\section{Manure management}

Most methane emissions from manure management are related to storage and anaerobic treatment. Although manure deposited on pasture can produce nitrous oxide emissions, the mitigation measures are often difficult to apply because of the manure dispersion on pasture. Therefore, most mitigation practices involve shortening storage duration, improving timing and application of manure, used of anaerobic digesters, covering the storage, using a solids separator, and changing the animal diets. Anaerobic digestion can reduce methane emissions while producing biogas [75]. Anaerobic digesters are lagoons or tanks that maintain manure under anaerobic conditions to capture biogas and combust it for producing energy or flaring. This process reduces the potential of GHG emissions by converting methane into $\mathrm{CO} 2$. Unfortunately, anaerobic digesters are costly for producers; the best approach for implementing digesters is through policies that create enough incentive for adaptation.

The solids separator is mostly used in confinement systems to remove solids from manure streams that are entering the treatment or storage systems. By removing the solids from manure streams methane emissions are reduced, the time between storage system cleaning is increased, and crust formation is prevented. These practices, compared to anaerobic digesters, are usually low-cost and low-tech. However, they require more time and effort from the producer. Adjusting animal diets can also be used as a mitigation measure, by changing the volume and composition of manure. GHG emissions can be reduced by balancing dietary proteins and feed supplements. If protein intake is reduced, the nitrogen excreted by animals can also be reduced. Supplements such as tannins are also known to have the potential to reduce emissions. Tannins are able to displace the nitrogen excretion from urine to feces to produce an overall reduction in emissions.

\section{Reducing enteric methane production}

A set of nutritional strategies proved efficient in reducing methane emissions in ruminants [77].

a. Replacing roughages with concentrates results in increased proportion of propionate in the rumen, thus less hydrogen available for $\mathrm{CH} 4$ production

b. Feeding legume forages results in less emission of $\mathrm{CH} 4$ than grass-based diets.

c. Feeding ensiled forages reduces methanogenesis.

d. Improving pasture management is associated with decreased $\mathrm{CH} 4$ emissions due to improved livestock productivity and a reduction of dietary fibre.

e. Administering plant extracts (condensed tannins, saponins, and essential oils) reduces $\mathrm{CH} 4$ emissions. Tannins have a direct effect on methanogenesis and indirect effect on hydrogen production due to lower feed degradation. Saponins, glycosides available in many plants, have direct effect on rumen microbes. They decrease protein degradation and favour at the same time microbial protein and biomass synthesis. Saponins induce protozoa suppression. Essential oils contain many biologically active molecules which have antimicrobial properties. Some compounds in essential oils are toxic to methanogens.

f. Supplementing ruminants with lipid sources (fat or oils) impacts negatively on methanogenesis by toxicity to methanogens, causes defaunation thus suppresses protozoa associated methanogens and decreases fibre digestion.

g. Administering ionophores like monensin in the diet results in a shift of bacterial population from gram positive to gram negative organisms with a concurrent shift in the fermentation from acetate to propionate [78].

\section{Carbon sequestration}

The success of strategies of greenhouse gas mitigation depends on the use of appropriate tools to reduce carbon losses and to increase carbon sequestration. A set of management practices that help achieve these objectives. We report below some of these practices that refer to grassland carbon sequestration [77] 
Avoiding soil tillage,

Moderately intensifying nutrient-poor permanent grasslands,

Avoid heavy grazing,

Grass-legumes association rather than grass only.

\section{Fertilizer management}

Fertilizer application on animal feed crops increases nitrous oxide emissions [79]. Therefore, mitigation measures such as increasing nitrogen use efficiency, plant breeding and genetic modifications, using organic fertilizers regular soil testing, using technologically advanced fertilizers, and combining legumes with grasses in pasture areas may decrease GHG emissions in feed production. Nitrogen use efficiency can be improved by applying the required amount that the crop will absorb and when it needs the nutrients, and placing it where the plant can easily reach it. Regular soil testing can be a part of a nutrient management plan depending on the region and crop, and improve efficiency of nitrogen use. Plant breeding and genetic modifications can reduce the use of fertilizers by increasing a crop's nitrogen uptake. Increasing the use of organic fertilizers would also decrease emissions because organic fertilizers do not produce as much nitrogen oxide as synthetic fertilizers. Furthermore, fertilizer technology has improved through regulating the release of nutrients from the fertilizer and inhibiting nitrification to slow the degradation of the fertilizer and maintain the nutrients available for the plant. However, these technologically advanced fertilizers are more costly than the other practices mentioned above. In the case of pasturelands, the use of synthetic nitrogen can be reduced by combining legumes with grasses. Legumes fix nitrogen through Rhizobium bacteria; therefore, the need for supplementary nitrogen is reduced [65].

\section{Shifting dietary}

Improved forages can be used as a climate change mitigation strategy in both developing and developed regions. Not only can improved pastures reduce $\mathrm{CH} 4$ emissions from animals, but carbon sequestration in grassland soils can also be increased by planting nitrogen-fixing legumes [80]. One strategy for mitigating methane emissions with feed changes is by including more concentrates in addition to, or in place of, a proportion of dietary forage [21]. Changes to animal diets can reduce greenhouse gas emissions and increase animal productivity, but they can also risk harming animal welfare. However, bolstering nutrition by supplementing poor diets or using improved forages can both reduce greenhouse gas emissions and improve welfare at the same time. In regions of the world with a seasonally dry tropical climate, such as Africa, the low nutritional value of most animal feeds during the dry season is a major constraint on animal productivity [81].

Options for mitigating climate change, which are subject to local context, include the following: Eliminating unproductive animals and increasing the overall efficiency of livestock production;

Selection of more productive livestock breeds where conditions allow

a. Improving rangelands through improved pasture management.

b. Enabling of transhumance and effective communal pasture management.

c. Reforestation and tree protection in pasture lands.

d. Restoration of degraded lands.

e. Improved waste management, including efficient use of manure as fertilizer.

f. Improved use of low fiber feed additives.

g. Improved energy/feed efficiency.

h. Breeding for improved productivity and efficiency in greenhouse gas emissions [82].

\section{Future Prospective (Scenarios)}

Globally, most of the available scenarios on climate change and their relationship with agriculture are pessimistic and predict a negative effect of global warming on production outputs. From another point of view, there is a consensus as to the difficulties to pinpoint the impact that can be attributed to global warming. Levels of agricultural production including livestock producers, are subject to important interactions between factors such as the use of inputs, the market forces and agricultural policies mainly subsidies and incentives. In addition, inter annual climatic variability is a major determinant of agricultural yields and this will not allow easy isolation of the effect attributed to global warming [83].

The most promising approach for reducing methane emissions from livestock is by improving the productivity and efficiency of livestock production, through better nutrition and genetics. Greater efficiency means that a larger portion of the energy in the animals' feed is directed toward the creation of useful products (milk, meat, and draught power), so that methane emissions per unit product are reduced. The increase in production efficiency also leads to a reduction in the size of the herd required to produce a given level of product. Because many developing countries are striving to increase production from ruminant animals (primarily milk and meat), improvements in production efficiency are urgently needed for these goals to be realized without increasing herd sizes and corresponding methane emissions [23]. To decrease the emission from manure management, it is necessary to reduce the animal number, to optimize the feed digestibility, to increase animal productivity and improve the efficiency of the manure management system [84]. 


\section{Conclusion and Recommendation}

\section{Conclusion}

Climate change and variability in Sub-Saharan Africa is already impacting negatively on rain-fed agriculture and livestock systems, caused by both natural and human activities (more than 90\%). Livestock sector in due climate change in the pattern and quantity of rainfall; an increase in temperature; changes in winds; changes in seasonality; more frequent catastrophic events; a decrease in feed and fodder production; reduced water availability; changing patterns and distribution of disease; changes in the marketing and prices of commodities. To enhance the ability of livestock survival in Africa on low quality feed, tolerant to emerging diseases, induced by unfavorable climatic conditions and slow emaciation rate during feed and water resource shortage should be integral part of an effective future livestock improvement strategy. Mitigation practices such as adjusting animal diets, shortening storage duration, improving timing and application of manure, used of anaerobic digesters, covering the storage, increasing nitrogen use efficiency, using a solids separator, replacing roughages with concentrates, improving energy/feed efficiency, avoid heavy grazing, plant breeding and genetic modifications, using organic fertilizers regular soil testing, using technologically advanced fertilizers, and combining legumes with grasses in pasture areas, administering plant extracts, feeding ensiled forages reduces methanogenesi and avoiding soil tillage are very important [8589].

\section{Recommendation}

a. Awareness creation/training on climate change, and improved capacity of herders/livestock producers to understand and deal with climatic changes

b. Research is needed on assessments for implementing these adaptation measures and tailoring them based on location and livestock system.

c. Should be develop the habit of feeding concentrates, legume forages and improving pasture management

d. Indigenous/native breeds improvement should be develop for more adaptive the climate change

e. Research will be focus on livestock improvement strategies for adopting genetic selection to mitigate the climate change

f. Should be improve more productive dairy cattle and reduce the number of dairy cows

g. Research will be done on feed related with more productive species and mitigate the climate change

h. Should be administering ionophores and becterocin in the diet of dairy cows.

\section{References}

1. WSPA (2012) Livestock production and climate change. Submission to the UNFCCC Subsidiary Body for Science and Technological Advice (SBSTA) consultation on livestock and climate change from the World Society for the Protection of Animals, World Society for the Protection of Animals, USA.

2. Fraser E (2009) Crop yield and climate change.

3. IPCC (2013) Climate Change 2013: The Physical Science Basis. Contribution of Working Group I to the Fifth Assessment Report of the Intergovernmental Panel on Climate Change. In: Stocker TF, D Qin, GK Plattner, M Tignor, SK Allen, et al. (Eds.), Cambridge University Press, Cambridge, United Kingdom and New York, NY, USA, pp. 1535.

4. Watson C, Catley A (2008) Network papers HPN. Livelihood livestock and humanitarian response: the livestock emergency guidelines and standards.

5. IPCC (2001) Climate Change 2001: Impacts, Adaptation and Vulnerability. Cambridge.

6. Casey K, Bicudo J, Schmidt D, Singh A, Gay S, et al. (2006) Air quality and emissions from livestock and poultry production/waste management systems 40, Animal Agriculture and the Environment: National Center for Manure and Waste Management White Papers.

7. Silva E, Mendes AB, Rosa HJD (2016) Dairy farming systems' adaptation to climate change. Agricultural Sciences, 7: 137-145.

8. IDF (2010) A common carbon footprint for dairy, The IDF Guide to Standard Lifecycle Assessment Methodology for the Dairy Industry. International Dairy Federation, Belgium.

9. Hounghton JT, Ding Y, Griggs DJ, Noguer N, van der Linden PJ (2001) Climate Change: The Scientific Basis. Contribution of Working Group I to the Third Assessment Report of the Intergovernmental Panel on Climate Change (Cambridge University Press) New York, USA.

10. Jungbluth T, E Hartung G Brose (2001) Greenhouse gas emissions from animal houses and manure stores. Nutrient Cycling in Agroecosystems 60(1-3): 133-145.

11. Seo SN, Mendelsohn R (2006) Climate change impacts on animal husbandry in Africa: A Ricardian analysis. CEEPA Discussion Paper No. 9, Centre for Environmental Economics and Policy in Africa, University of Pretoria, South Africa.

12. Angilletta MJ (2009) Looking for answers to questions about heat stress: researchers are getting warmer. Functional Ecology, pp. 231232.

13. Lawrence AB, E Wall (2014) Selection for 'environmental fit' from existing domesticated species. Rev Sci Tech Off Int Epiz 33(1): 171-179.

14. Godfray HJ, IR Crute, L Haddad, D Lawrence, JF Muir, et al. (2010) The future of the global food system. Philosophical Transactions of the Royal Society 365(1554): 2769-2777.

15. Walshe NJ, Grindle J, Nell A, Bachman M (1991) Dairy development in ssa:a study of issues and options. World technical paper 135, World Bank, Washington DC, USA, p. 94.

16. Dereje T, A Workneh, BP Hegde (2005) Survey of traditional cattle production systems and preferred cattle functions in North and South Wollo Zones, Ethiopia. Ethiopian Veterinary Journal 9(1): 91-108.

17. Sintayehu Yigrem, Fekadu Beyene, Azage Tegegne and Berhanu Gebremedhin, 2008. Dairy production, processing and marketing systems of Shashemene-Dilla area, South Ethiopia. IPMS (Improving Productivity and Market Success) of Ethiopian Farmers Project Working Paper 9. ILRI (International Livestock Research Institute), Nairobi, Kenya. 62p. 
18. Asrat A, Zelalem Y, Ajebu N (2013) Characterization of milk production systems in and around Boditti, South Ethiopia. Int J lrrd 25(10).

19. Wold GA, Alemayehu M, Demeke S, Bediye S, Tadesse A (2000) Status of dairy development. Smallholder Dairy Development Project (SDDP) dairy research in Ethiopia. In: The role of village dairy co-operatives in dairy development. SDDP (Smallholder Dairy Development Project) Proceedings, MOA (Ministry of Agriculture), Addis Ababa, Ethiopia.

20. Ahmed M, Ehui S, Assefa Y (2004) Dairy development in Ethiopia. Environment and production technology division. International Food Policy Research Institute, USA.

21. IPCC (2007) Mitigation of climate change. Contribution of working group III to the fourth assessment report of the intergovernmental panel on climate change. Cambridge University Press: Cambridge, New York, NY, USA.

22. Nzuma, J.M., M. Waithaka, R. M. Mulwa, M. Kyotalimye and G. Nelson, 2010. Strategies for adapting to climate change in rural Sub-Saharan Africa. A review of data sources, poverty reduction strategy programs (PRSPs) and national adaptation plans for agriculture (NAPAs) in ASARECA Member Countries.

23. Steinfeld H, Gerber P, Wassenaar T, Castel V, Rosales M, et al. (2006) Livestock's long shadow: environmental issues and options. FAO, Rome, Italy.

24. McKee J (2008) Deconstructing some myths about climate change adaptation and mitigation, In: Green Forum (Ed.), Climate change - a burning issue for Ethiopia: proceedings of the $2^{\text {nd }}$ Green Forum Conference held in Addis Ababa, pp. 111-135.

25. IPCC (2014) Summary for policymakers. In: Climate change 2014: Impacts, adaptation, and vulnerability. Part A: Global and sectoral aspects. Contribution of working group II to the fifth assessment report of the intergovermental panel on climate change. Cambridge University Press, Cambridge, UK and New York, USA, pp. 132.

26. Hulme M, Doherty RM, Ngara T, New MG, Lister D, et al. (2001) African climate change: 1900-2100. Climate Research 17(2): 145-168.

27. Christensen JH, Hewitson B, Busuioc A, Chen A, Gao X, et al. (2007) Regional Climate Projections. Climate Change 2007: The Physical Science Basis. Contribution of Working Group I to the Fourth Assessment Report of the Intergovernmental Panel on Climate Change. Cambridge University Press, UK.

28. Christine J (2002) Facilitating the survival of African pastoralism in the Face of Climate Change: Looking back to move forward. Tufts University, Massachusetts, USA.

29. Boko M, Niang I, Nyong A, Vogel C, Githeko A, et al. (2007) In Climate change: impacts, adaptation and vulnerability. Contribution of Working Group II to the Fourth Assessment Report of the Intergovernmental Panel on Climate Change, Parry ML, Canziani OF, Palutikof JP, van der Linden PJ, Hanson CE (eds.), Cambridge University Press, UK, pp. 433467.

30. Nicholson SE, Entekhabi D (1986) The quasi-periodic behavior of rainfall variability in Africa and its relationship to the Southern Oscillation. Journal of Climate applied Meteorology 34: 331-348.

31. Bebe BO, Udo HMJ, Rowlands GJ, Thorpe W (2003) Smallholder dairy systems in the Kenya highlands: Cattle population dynamics under increasing intensification. Livestock Production Science 82(2-3): 211221.

32. Siemes H (2008) Climate change - dairy sector will take the bull by the horns.

33. FAO (2006) Livestock's long shadow: environmental issues and options. Food and Agriculture Organization, Rome, Italy.

34. FAO (2010) Greenhouse gas emissions from the dairy sector: A life cycle assessment. Rome: Food and Agriculture Organization, Italy.
35. Flysjö A, Henriksson M, Cederberg C, Ledgard S, JE Englund, et al. (2011) The impact of various parameters on the carbon footprint of milk production in New Zealand and Sweden. Agricul Syst (in press).

36. Lassey KR, (2007) Livestock methane emission: From the individual grazing animal through national inventories to the global methane cycle. Agric For Meteor 142: 12-132.

37. Van den Bossche P, Coetzer JAW (2008) Climate change and animal health in Africa Review Science Technology off. int. Epiz 27(2): 551562.

38. Gardner I (2012) Strengthening Tanzanian Livestock Health and Pastoral Livelihoods in a Changing Climate.

39. Davison T, McGowan M, Mayer D, Young, N Jonsson (1996) Managing hot cows in Australia. Queensland Department of Primary Industry, Australia, p. 58.

40. Jones RN, KJ Hennessy (2000) Climate change impacts in the Hunter Valley. A risk assessment of heat stress affecting dairy cattle. CSIRO Atmospheric Research.

41. Berman AJ (2005) Estimates of heat stress relief needs for Holstein dairy cows. J Anim Sci 83(6):1377-1384.

42. Ravagnolo O, Misztal I (2000) Genetic component of heat stress in dairy cattle, parameter estimation. J Dairy Sci 83: 2126-2130.

43. Nardone A, Ronchi B, Lacetera N, Bernabucci U (2006) Climatic effects on productive traits in livestock. Veterinary Research Communications 30 (suppl 1): 75-81.

44. Marai IFM, El-Darawany AA, Fadiel A, Abdel-Hafez MAM (2007) Physiological traits as affected by heat stress in sheep-a review. Small Rumin Res 71: 1-12.

45. Rowlinson P (2008) Adapting livestock production systems to climate change - temperate zones. In: Rowlinson P, Steele M, et al. (Eds.) Livestock and global change. Proceedings of an international conference, Hammamet, Tunisia, Cambridge University Press, Cambridge, UK, p. 61-63.

46. Chebel RC, JEP Santos, JP Reynolds, RLA Cerri, M Overton (2004) Factor affecting conception rate after artificial insemination and pregnancy loss in lactating dairy cows. Anim Rep Sci 84(3-4): 239-255.

47. Bilby TR, Baumgard LH, Collier RJ, Zimbelman RB, Rhoads ML, et al. (2008) Heat stress effects on fertility: Consequences and possible solutions. Proc Southwest Nutr Conf 177: 193-124.

48. Wilson SJ, Marion RS, Spain JN, Spiers DE, Keisler DE, et al. (1998) Effects of controlled heat stress on ovarian function of dairy cattle. 1 . Cows. J Dairy Sci 81: 2139-2144.

49. Ronchi B, Stradaioli G, Supplizi V, Bernabucci U, Lacetera N, et al. (2001) Influence of heat stress and feed restriction on plasma progesterone, estradiol-17 $\beta$ LH, FSH, prolactin and cortisol in Holstein heifers. Livest Prod Sci 68: 231-241.

50. Rensis FD, Scaramuzzi RJ (2003) Heat stress and seasonal effects on reproduction in the dairy cow - a review. Theriogenology 60: 11391151.

51. Collier R, SG Doelger, HH Head, WW Thatcher, CJ Wilcox, et al. (1982) Effects of heat stress during pregnancy on maternal hormone concentrations, calf birth weight and postpartum milk yield of Holstein cows. J Anim Sci 54(2): 309-319.

52. Devendra C, Thomas D, Jabbar M, Zerbini E (2000) Improvement of Livestock Production in Crop-Animal Systems in Agro-Ecological Zones of South Asia. ILRI, Kenya.

53. Forman S, N Hungerford, M Yamakawa, T Yanase, HJ Tsai (2008) Climate change impacts and risks for animal health in Asia. Rev Sci Tech 27(2): 581-597. 
54. Guernier V, ME Hochberg, JF Guegan (2004) Ecology drives the worldwide distribution of human diseases. PLOS Biology 2(6): 740746.

55. Minson DJ (1990) Forage in Ruminant Nutrition. Academic Press, San Diego, Calfornia, USA.

56. Thornton P, van de Steeg J, Notenbaert MH, Herrero M (2009) The impacts of climate change on livestock and livestock systems in developing countries: A review of what we know and what we need to know. Agri Systems 101: 113-127.

57. IFAD (2010) Livestock and climate change. Livestock Thematic Papers. Tools for project design.

58. Nardone A, Ronchi B, Lacetera N, Ranieri MS (2010) Effects of climate change on animal production and sustainability of livestock systems. Livest Sci 130: 57-69.

59. De Wit M, Jacek S (2006) Changes in surface water supply across Africa with predicted climate change - AEON - Africa earth observatory network, University of Cape Town, South Africa, science express report.

60. Hoffman MT, C Vogel (2008) Climate Change Impacts on African Rangelands. Rangelands 30: 12-17.

61. Aklilu A, Desalegn W, Mesfin K, Negash T (2013) Climate change impacts on Pastoral Women in Ethiopia: Some evidences from the Southern lowlands. PHE Ethiopia Consortium. p. 1 -6.

62. Coffey S (2008) A Systems Approach to Climate Change Impacts on Livestock Production. Paper prepared for presentation at the "Agriculture in A Changing Climate: The New International Research Frontier" conference conducted by the Crawford Fund for International Agricultural Research, Australia, pp. 39-48.

63. Adams R, Hurd B, Lenhart S, Leary N (1998) Effects of global climate change on agriculture: an interpretative review. Inter-Research 11: 1930 .

64. FAO (2009) Enabling agriculture to contribute to climate change mitigation. FAO, Italy.

65. USDA (2007) Dairy 2007, Part I: Reference of Dairy Cattle Health and Management Practices in the United States, 2007. USDA-APHIS-VS, Fort Collins, CO.

66. Abebe K (2017) Effect of climate change on nutritional supply to livestock production. Acad Res J Agri Sci Res 5(2): 98-106.

67. Sidahmed A (2008) Livestock and climate change: Coping and risk management strategies for a sustainable future. In livestock and global climate change conference proceeding, Tunisia.

68. Mortimore MJ, Adams WM (2001) Global Environmental Change 11: 49-57.

69. Thornton P, Herrero M, Freeman A, Mwai O, Rege E, (2007) Vulnerability climate change and livestock - research opportunities and challenges for poverty alleviation. An Open Access Journal published by ICRISAT.

70. Jones HE, Warkup CC, Williams A, Audsley E (2008) The effect of genetic improvement on emission from livestock systems. In Proceedings of the $59^{\text {th }}$ Annual Meeting of the European Association for Anima Production, Vilnius, Lithuania, Wageningen Academic Publishers: Vilnius, Lithuania, 14: 28

71. ATPS (African Technology Policy Studies Network) (2013) Vulnerability and adaptation strategies to climate variability and change of the Bostaurus dairy genotypes under diverse production environments in Kenya, ATPS research paper p. 23.

72. Cottle DJ, JV Nolan, SG Wiedemann (2011) Ruminant enteric methane mitigation: a review. Animal Production Science 51(6): 491-514.
73. Pankaj PK, Ramana DBV, Pourouchottamane R, Naskar S (2013) Livestock Management under Changing Climate Scenario in India. World Journal of Veterinary Science 1: 25-32.

74. Never A (2015) Focusing on livestock improvement strategies that enhance adaptive and coping mechanisms in the context of climate change in southern Africa. Scientific Journal of Animal Science 4(6): 72-80.

75. Gerber P, Vellinga T, Opio C, Henderson B, Steinfeld H, et al. (2010) Greenhouse Gas Emissions from the Dairy Sector, A Life Cycle Assessment. FAO Food and Agriculture Organisation of the United Nations, Animal Production and Health Division, Italy.

76. O’Mara FP, Beauchemin KA, Kreuzer M, McAllister TA (2008) Reduction of greenhouse gas emissions of ruminants through nutritional strategies. In: Rowlinson P, Steele M, et al. (Eds.) Livestock and global change. Proceedings of an international conference, Hammamet, Tunisia, Cambridge University Press, Cambridge, UK, p. 40-43.

77. Soussana JF, Tallec T, Blanfort V (2010) Mitigating the greenhouse gas balance of ruminant production systems through carbon sequestration in grasslands. Animal 4(3): 334-350.

78. Moss AR, Jouany JP, Newbold J (2000) Methane production by ruminants: its contribution to global warming. Ann. Zootech 49: 231 253.

79. Bouwman A (1996) Direct emissions of nitrous oxide from agricultural soils. Nutrient Cycling in Agroecosystems 46: 53-70.

80. Liebig MA, Hendrickson JR, Berdahl JD (2010) Response of soil carbon and nitrogen ton transplanted alfalfa in North Dakota rangeland. Can J Soil Sci 90: 523-526.

81. Tothill JC (1985) The role of legumes in farming systems of SubSaharan Africa. Potentials of forage legumes in farming systems of Sub-Saharan Africa. In: Proceedings of a workshop held at ILCA, Addis Ababa, Ethiopia, p. 16-19.

82. BCCRALSSA (Building climate change resilience for African livestock in sub-Saharan Africa) (2010) World Initiative for Sustainable Pastoralism (WISP): a program of IUCN - The International Union for Conservation of Nature, Eastern and Southern Africa Regional Office, Nairobi, p. 48.

83. Salem HB, Rekik M, Lassoued N, Darghouth MA (2011) Global warming and livestock in dry Areas: Expected impacts, adaptation and mitigation, IntechOpen Ltd, London, UK.

84. Bates J (2001) Economic Evaluation of Emission Reductions of Nitrous Oxides and Methane in Agriculture in the EU.

85. Garnett T, Godfray HCJ (2012) Sustainable intensification in agriculture. Oxford: Food Climate Research Network and the Oxford Martin Programme on the Future of Food, University of Oxford, UK.

86. Gerber PJ, Steinfeld H, Henderson B, Mottet A, Opio C, et al. (2013) Tackling climate change through livestock - A global assessment of emissions and mitigation opportunities, Italy.

87. Iqubal A (2013) Livestock Husbandry - A sustainable livelihood in Ethiopia. international Journal of Economy, Management and Social Sciences. 2(8): 603-607

88. Niang I, Ruppel OC, Abdrabo MA, Essel A, Lennard C, et al. (2014) Africa. In: Climate change 2014: impacts, adaptation and vulnerability. Contribution of Working Group II to the Fifth Assessment Report of the Intergovernmental Panel on Climate Change. Cambridge University Press, Cambridge, UK.

89. Rhoads ML, Rhoads RP, VanBaale MJ, Collier RJ, Sanders SR, et al. (2009) Effects of heat stress and plane of nutrition on lactating Holstein cows: I. production, metabolism and aspects of circulating somatotropin. Dairy Sci 92: 1986-1997. 
This work is licensed under Creative Commons Attribution 4.0 License

DOI: 10.19080/ARTOAJ.2018.16.555997

\section{Your next submission with Juniper Publishers} will reach you the below assets

- Quality Editorial service

- Swift Peer Review

- Reprints availability

- E-prints Service

- Manuscript Podcast for convenient understanding

- Global attainment for your research

- Manuscript accessibility in different formats

( Pdf, E-pub, Full Text, Audio)

- Unceasing customer service

Track the below URL for one-step submission https://juniperpublishers.com/online-submission.php 